\title{
Application of Atmospheric Non Thermal Plasma-Catalysis Hybrid System for Air Pollution Control: Toluene removal.
}

\author{
H. Than Quoc An ${ }^{1}$, T. Pham Huu ${ }^{1}$, T. Le Van ${ }^{1}$, J. M. Cormier ${ }^{2}$, and A. Khacef ${ }^{2 \dagger}$ \\ ${ }^{1}$ Institute of Applied Material Science, VAST, 1 Mac Dinh Chi, HCMC, Vietnam, \\ ${ }^{2}$ GREMI, PolyTech'Orléans, 14 rue d'Issoudun, BP 6744, 45067 Orléans Cedex 02, France.
}

Keywords: Non thermal Plasma, Catalysis, Toluene, oxidation.

\begin{abstract}
The combination of heterogeneous catalysts with non-thermal plasma (DBD operated in sinusoidal mode) was investigated for the removal of toluene from air at room temperature. The DBD reactor gives the possibility to introduce the heterogeneous catalyst directly into the discharge zone (in-plasma catalysis, IPC) or to place the catalyst downstream the plasma zone (post-plasma catalysis, PPC). Various catalytic materials based on $\mathrm{Ag}, \mathrm{Au}, \mathrm{Cu}, \mathrm{Co}, \mathrm{Mn}, \mathrm{La}$, and $\mathrm{Nb}$, supported on $\mathrm{Al}_{2} \mathrm{O}_{3}$ and $\mathrm{CeO}_{2}$ in powder form has been tested to select the catalysts that present the highest activity in the presence of plasma.

Without plasma, the reaction of toluene conversion over perovskite, $\mathrm{Al}_{2} \mathrm{O}_{3}$, and OMS-2 based catalysts are promoted at high temperature $\left(200-400^{\circ} \mathrm{C}\right)$. In the absence of catalysts, the toluene removal efficiencies were in the $55-60 \%$ range.

When the plasma was combined to catalyst, the toluene removal efficiency strongly increased when the catalysts are in IPC position. Best results, up to $96 \%$ toluene conversion, were obtained when using $1 \mathrm{wt} \% \mathrm{Au} / \mathrm{Al}_{2} \mathrm{O}_{3}$ and $\mathrm{Nb}_{2} \mathrm{O}_{5}$ catalysts.
\end{abstract}

\section{Introduction}

Volatile organic compounds (VOCs) are an important category of air pollutants and therefore, become a serious problem for damaging the human health and the environment in general $[1,2]$. Well established technologies for VOC abatement are thermal and catalytic oxidation, adsorption, condensation, biofiltration, membrane separation or ultra-violet oxidation $[3,4]$. The thermal and catalytic methods, which are widely used, are very efficient to oxidize VOCs. However, these technologies which require a substantial supply of thermal energy (in the range of $700-800^{\circ} \mathrm{C}$ for thermal incineration and $200-600^{\circ} \mathrm{C}$ for catalytic oxidation) are not well adapted and energetically expensive in the case of moderate gas flow rates containing low VOC concentrations. In addition, the catalyst poisoning followed by deactivation represents a serious problem for these technologies.

As an alternative to conventional VOCs abatement techniques, atmospheric non-thermal plasma (NTP) technology received increasing interest during the last decade [5-12] for the removal of dilute VOCs from many sources. The main advantage of these non equilibrium plasmas consists in the ability to generate high-energy electrons, while keeping the background gas close to room temperature. Thus, a highly reactive environment is created without spending energy on gas heating as in thermal processes. The energetic electrons excite, dissociate and ionize the gas molecules producing chemically active species. VOCs removal is generally attributed to radical reactions initiated by $\mathrm{O}$ or $\mathrm{OH}$ radicals [13, 14].

\footnotetext{
$\dagger$ Corresponding author: ahmed.khacef@univ-orleans.fr

Tel: + 33238494875

Fax: + 33238417154
} 
However, depending on the reaction conditions, other radical and ionic reactions also result in VOC conversion to $\mathrm{CO}_{2}, \mathrm{H}_{2} \mathrm{O}$ and other degradation products $[15,16]$.

Atmospheric pressure NTPs for environmental applications may be produced by a variety of electrical discharge devices (corona, surface, and dielectric-barrier discharges) [17-20]. For some industrial and domestic applications, pulsed discharges are much more suited because of their high selectivity, capability of removing various pollutants simultaneously, moderate operating conditions, and relatively low maintenance requirements resulting in relatively low energy costs of the pollutant treatment. However, NTP technology for indoor air treatment has the disadvantage to produce undesirable byproducts such as ozone and NOx [21-23]. To overcome the by-products formation and increasing energy efficiency, non thermal plasma could take advantage of its synergetic effect through combination with heterogeneous catalysts [9]. This combination can be either single-stage or two-stage. In the two-stage system, the catalyst materials are usually placed downstream from NTP reactor. In the single stage system, the catalysts are placed directly in the NTP reactor.

In this work, various catalytic materials were combined with a dielectric barrier discharge (DBD) for VOC abatement at room temperature. Reported results concern the catalyst effect, the plasma effect and the plasma-catalyst effect on the conversion efficiency of toluene used as a representative VOC. A systematic investigation is carried out in order to select the optimal positioning of the catalyst regarding the plasma discharge (inside the plasma or in post-plasma).

\section{Experimental set-up}

\subsection{Plasma reactor}

The plasma reactor we used is a dielectric-barrier discharge (DBD) reactor in a cylindrical configuration. A schematic view of DBD reactor is shown in figure 1. It consist consisted of a $1.5 \mathrm{~mm}$-diameter tungsten wire centered in a $20 \mathrm{~mm}$ long dielectric tube, and fixed with two ceramic rings. The outer surface of tube was coated with a brass wire to form the outer electrode. The length of the discharge zone can be adjusted and then determine the active volume of the plasma reactor. That configuration gives the possibility to combine heterogeneous catalyst with plasma reactor in two different ways: by introducing the catalyst in the discharge zone (in-plasma catalysis, IPC configuration) or by placing the catalyst downstream the discharge zone (post-plasma catalysis, PPC configuration) (Figure 1a and b). The plasma reactor was powered by a high voltage AC generator delivering $\mathrm{HV}$ amplitude up to $18 \mathrm{kV}$ at a frequency of $50 \mathrm{~Hz}$.

Gas containing mixtures of $\mathrm{O}_{2}, \mathrm{~N}_{2}$, and toluene was prepared in a gas handling system and their composition was controlled with calibrated flow meters. Experiments were conducted at total flow rate of $3 \mathrm{~L} / \mathrm{h}$ and toluene concentration of about $800 \mathrm{ppm}$. The experiment was carried out at room temperature and atmospheric pressure.

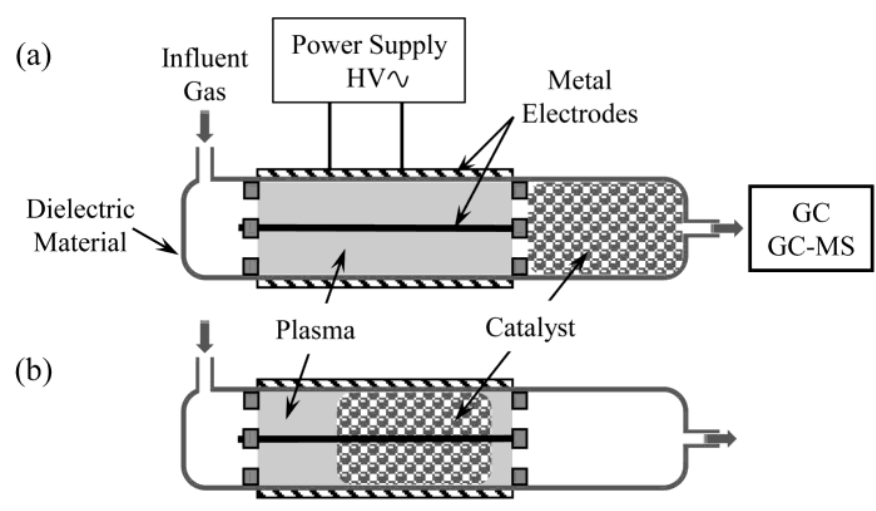

Figure 1: Schematic overview of the two plasma-catalyst hybrid configurations:

(a) Post-Plasma Configuration (PPC), (b) In-Plasma Configuration (IPC). 


\subsection{Materials}

Various catalytic materials based on $\mathrm{Ag}, \mathrm{Au}, \mathrm{Cu}, \mathrm{Co}, \mathrm{Mn}, \mathrm{La}$, and $\mathrm{Nb}$, supported on $\mathrm{Al}_{2} \mathrm{O}_{3}$ and $\mathrm{CeO}_{2}$ in powder form, have been tested to select the catalysts presenting the highest activity in the presence of non-thermal plasma operating at low temperature (room temperature). These catalysts include: OMS-2 (cryptomelane type manganese octahedral molecular sieve), 5-15wt\%CuO/OMS-2, 510wt $\% \mathrm{Co}_{2} \mathrm{O}_{3} / \mathrm{OMS}-2, \quad \mathrm{CeO}_{2}, \quad 1 \mathrm{wt} \% \mathrm{Au} / \mathrm{Ce}_{2} \mathrm{O}_{3}, \quad \mathrm{Al}_{2} \mathrm{O}_{3}, \quad 5-15 \mathrm{wt} \% \mathrm{Co}_{2} \mathrm{O}_{3} / \mathrm{Al}_{2} \mathrm{O}_{3}, \quad 1-2 \mathrm{wt} \% \mathrm{Ag} / \mathrm{Al}_{2} \mathrm{O}_{3}$, $1 \mathrm{wt} \% \mathrm{Au} / \mathrm{Al}_{2} \mathrm{O}_{3}, \mathrm{LaMnO}_{3}, \mathrm{LaMnO}_{3} / \mathrm{Al}_{2} \mathrm{O}_{3}, \mathrm{La}_{0.7} \mathrm{Ag}_{0.3} \mathrm{MnO}_{3}, \mathrm{La}_{0.7} \mathrm{Ag}_{0.3} \mathrm{MnO}_{3} / \mathrm{Al}_{2} \mathrm{O}_{3}, \mathrm{Nb}_{2} \mathrm{O}_{5}$.

\subsubsection{Catalysts preparation}

Except $\mathrm{CeO}_{2}, \mathrm{Al}_{2} \mathrm{O}_{3}$, and $\mathrm{Nb}_{2} \mathrm{O}_{5}$ catalysts, all the other catalysts were prepared by different methods. The supported metal catalysts were prepared by the wetness impregnation method. The aqueous solutions of nitrate salt $\left(\left(\mathrm{Cu}\left(\mathrm{NO}_{3}\right)_{2} .3 \mathrm{H}_{2} \mathrm{O}, \mathrm{Co}\left(\mathrm{NO}_{3}\right)_{2} 6 \mathrm{H}_{2} \mathrm{O}, \mathrm{AgNO}_{3}\right.\right.$, ) were slowly heated at $70^{\circ} \mathrm{C}$ until all the precursor was completely dissolved. A calculated amount of the support (OMS-2, $\mathrm{Al}_{2} \mathrm{O}_{3}, \mathrm{Nb}_{2} \mathrm{O}_{5}$, and $\mathrm{CeO}_{2}$ ) was added to the solution. The slurry was heated to approximately $80-100^{\circ} \mathrm{C}$ and stirred until the total evaporation of water. The samples thus obtained were dried at $120^{\circ} \mathrm{C}$ during 5 hours. The powder was crushed using a mortar and pestle and subsequently calcined at $500^{\circ} \mathrm{C}$ in air for 4 hours.

The Au/support catalysts were prepared by the deposition-precipitation method with urea [24].

The OMS-2 catalysts were prepared by the hydrothermal method as described in [25]. Two solutions ( $\mathrm{x}(\mathrm{g}) \mathrm{KMnO}_{4}$ in $100 \mathrm{ml} \mathrm{H} \mathrm{H}_{2} \mathrm{O}$, and $\mathrm{y}(\mathrm{g}) \mathrm{MnSO}_{4} \cdot \mathrm{H}_{2} \mathrm{O}$ in $300 \mathrm{ml} \mathrm{H}_{2} \mathrm{O}$ with adding $\mathrm{HNO}_{3}$ to maintain the $\mathrm{pH}$ at 1.2$)$ were heated to $100^{\circ} \mathrm{C}$ during $24 \mathrm{~h}$. The precipitate was recovered by filtration, washed and dried in air (120 $\mathrm{C}$ during 12 hours) and calcined in static air using a range of times and temperatures.

Finally, the $\mathrm{LaMnO}_{3}$ and $\mathrm{La}_{0.7} \mathrm{Ag}_{0.3} \mathrm{MnO}_{3}$ catalysts were prepared by the citrate method. All the catalysts were also characterized after reaction by XRD, IR Spectroscopy, and FESEM.

The catalytic tests were made in continuous flow system at a total flow rate of about $4 \mathrm{~L} / \mathrm{h}$ at room temperature $\left(30^{\circ} \mathrm{C}\right)$. The weight of the catalysts in powder form was about $200 \mathrm{mg}$.

\subsubsection{Catalysts characterization}

The catalysts characterization was performed by XRD, FE-SEM, BET, and IR. The X-ray diffraction (XRD) measurements were performed on the catalysts with a Siemens D500 diffractometer using the $\mathrm{K}_{\alpha}$ line of $\mathrm{Cu}$ at $\lambda=1.5418 \AA$. The $2 \theta$ range was recorded between 5 and $80^{\circ}$ at a rate of $0.02 \mathrm{~s}^{-1}$. The infrared spectroscopy (IR) was carried out with Brucker Tensor 37. The BET (Brunauer, Emmett and Teller) surface area, $\mathrm{S}_{\mathrm{BET}}$, of the catalysts was measured by nitrogen adsorption-desorption method at $77 \mathrm{~K}$ using NOVA 1200 surface area analyzer (Quantachrome).

\subsection{Oxidation experiments}

The activity measurements were performed in a continuous flow fixed-bed reactor. The total flow rate through the catalyst bed was kept constant at $3 \mathrm{~L} / \mathrm{h}$ (oxygen: $0.8 \mathrm{~L} / \mathrm{h}$, nitrogen: $2.2 \mathrm{~L} / \mathrm{h}$ ) leading a weight hourly space velocity (WHSV) of about $20000 \mathrm{~h}^{-1}$ ). The toluene concentration was fixed at about $800 \mathrm{ppm}$. Under standard reaction conditions, this gas mixture was fed over $200 \mathrm{mg}$ catalysts introduced in the plasma reactor in post-plasma or in-plasma configuration.

The reactants and reaction products were analyzed by gas chromatography (INTERSMAT IGC 120FL) equipped with FID and SE $3010 \%$ Column (1.5 m length, interior diameter $0.18 \mathrm{~mm}$ ) and by gas chromatography coupled with mass spectrometer (GC-MS).

The analyses of the products were performed by GC HP 6890 Series II equipped with electron capture detector (ECD), phenomenex ZB5 column $(30 \mathrm{~m} \times 0.25 \mathrm{~mm}$, i.d. of $0.25 \mu \mathrm{m})$ and GC-MS Agilent Technologies 5973 equipped with flame ionization detector (FID), HP5 column (30 m x $0.18 \mathrm{~mm}$, i.d. of $0.32 \mu \mathrm{m})$. 


\section{Results}

Systematic experiments of toluene conversion were carried out in three systems: only heterogeneous catalysts, only NTP, and NTP-catalyst system with two combinations: in-plasma catalysis (IPC) and postplasma catalysis (PPC).

\subsection{Toluene removal by heterogeneous catalysis}

The catalytic activity is expressed in terms of the temperature $\left(\mathrm{T}_{\mathrm{e}}\right)$ required for $95 \%$ conversion of toluene. The temperature of catalytic ignition $\left(\mathrm{T}_{\mathrm{i}}\right)$ corresponds to the beginning of the catalytic reaction. Figure 2 shows the data giving $T_{i}$ and $T_{e}$ for toluene conversion as a function of the nature of catalyst. The reaction of toluene conversion over perovskite, $\mathrm{Al}_{2} \mathrm{O}_{3}$, and OMS-2 based catalysts are promoted at high temperature. As example, these data indicates that $\mathrm{T}_{\mathrm{i}}$ and $\mathrm{T}_{\mathrm{e}}$ are in the range of $300-480^{\circ} \mathrm{C}$ in the case of $\mathrm{Al}_{2} \mathrm{O}_{3}$, and $200-400^{\circ} \mathrm{C}$ when OMS-2 was used. In the presence of catalyst modified with $\mathrm{Cu}, \mathrm{Co}$, $\mathrm{Ag}$, or $\mathrm{Au}$, the ignition temperature decreases drastically to reach $90^{\circ} \mathrm{C}$ in the case of $1 \mathrm{wt} \% \mathrm{Au} / \mathrm{Al}_{2} \mathrm{O}_{3}$.

The supported metals on OMS-2 need a high loading (10-15wt\%) of $\mathrm{Cu}$ or Co to reach a high activity. In comparison to OMS-2 alone, the temperature of the end of reaction over $15 \mathrm{wt} \% \mathrm{Cu} / \mathrm{OMS}-2$ decreases from $400^{\circ} \mathrm{C}$ to $250^{\circ} \mathrm{C}$. Obviously, adding $\mathrm{Co}, \mathrm{Ag}$, or $\mathrm{Cu}$ creates new active sites which change the activity of the catalysts. Similar behavior was observed in the case of perovskite catalyst.

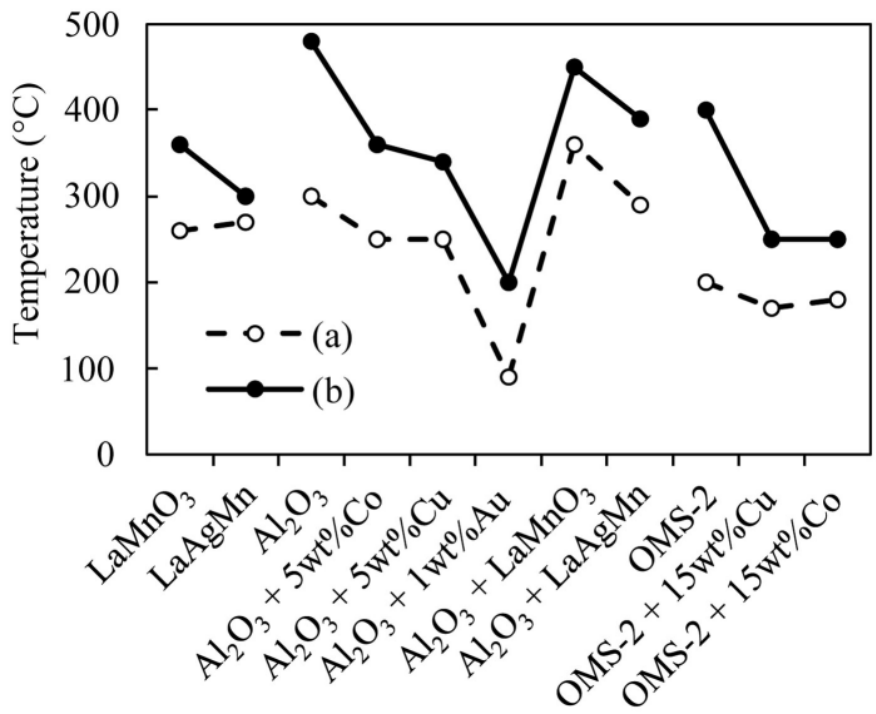

Figure 2: Toluene oxidation temperatures: Ignition reaction (a) and end reaction (b) as a function of the nature of catalysts.

\subsection{Toluene removal by NTP without catalyst}

In the absence of catalyst material, the plasma plays a role of "oxidative media". A significant fraction of input plasma energy is dissipated in the dissociation of $\mathrm{O}_{2}$ which becomes the dominant process because $\mathrm{O}_{2}$ dissociation is much more efficient than $\mathrm{N}_{2}$ dissociation in the electron energy range produced. This dominant oxidation process leads to the formation of the main products of the plasma such as $\mathrm{O}_{3}, \mathrm{CO}$, $\mathrm{CO}_{2}$, and $\mathrm{NOx}\left(\mathrm{NO}, \mathrm{NO}_{2}\right)$. In our experimental conditions, toluene conversions in the range 55- $60 \%$ were obtained. As expected, the plasma partially oxidizes the toluene leading to the formation of byproducts such as formic acid $\left(\mathrm{CH}_{2} \mathrm{O}_{2}\right)$, acetic acid $\left(\mathrm{C}_{2} \mathrm{H}_{4} \mathrm{O}_{2}\right)$, and benzene $\left(\mathrm{C}_{6} \mathrm{H}_{6}\right)$.

\subsection{Toluene removal efficiency by NTP/Catalyst hybrid system}

Systematic experiments were carried out for the two catalyst positions in regard to plasma reactor. When the IPC is operated, short lifetime reactive species, in the range of tens of nanoseconds, as radicals and excited states $\left(\mathrm{O}\left({ }^{3} \mathrm{P}\right), \mathrm{O}\left({ }^{1} \mathrm{D}\right), \mathrm{OH},\right)$ created by the NTP can be used efficiently by the catalyst. On the 
contrary, when the catalyst is placed post-plasma (PPC), long lifetime reactive species, in the range of milliseconds, such as $\mathrm{O}_{3}, \mathrm{H}_{2} \mathrm{O}_{2}, \mathrm{NO}$, and $\mathrm{NO}_{2}$ could be used.

The NTP-catalyst hybrid system is operated at room temperature. The toluene removal efficiency significantly increases when the catalyst was coupled to the plasma reactor whatever the nature of catalyst used. The toluene conversion measured over $0-15 \mathrm{wt} \% \mathrm{Cu} / \mathrm{OMS}-2$ catalysts is reported Figure 3 . By increasing the loading of $\mathrm{Cu}$ from 0 to $15 \mathrm{wt} \%$, the toluene conversion increases from 70 to $79 \%$ for IPC and from 65 to $69 \%$ for PPC. Similar results were obtained when Co was substituted to $\mathrm{Cu}$ at the same contents.

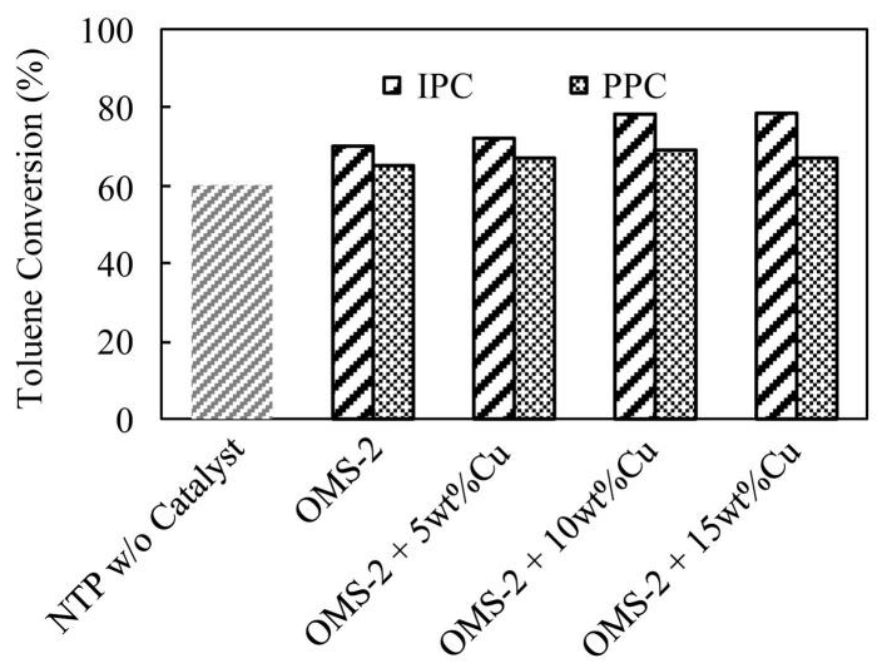

Figure 3: Toluene conversion over OMS-2 supported Cu catalysts.

Figure 4 shows toluene conversions over alumina based catalysts. Results clearly show that the highest toluene conversion (up to $96 \%$ ) was obtained when $1 \mathrm{wt} \% \mathrm{Au} / \mathrm{Al}_{2} \mathrm{O}_{3}$ was used into the plasma discharge. However, when these catalysts were positioned in the post-discharge region, lower toluene removal (up to $80 \%$ ) was measured. One can notice that, in the absence of catalyst, the toluene removal efficiency was only $60 \%$.

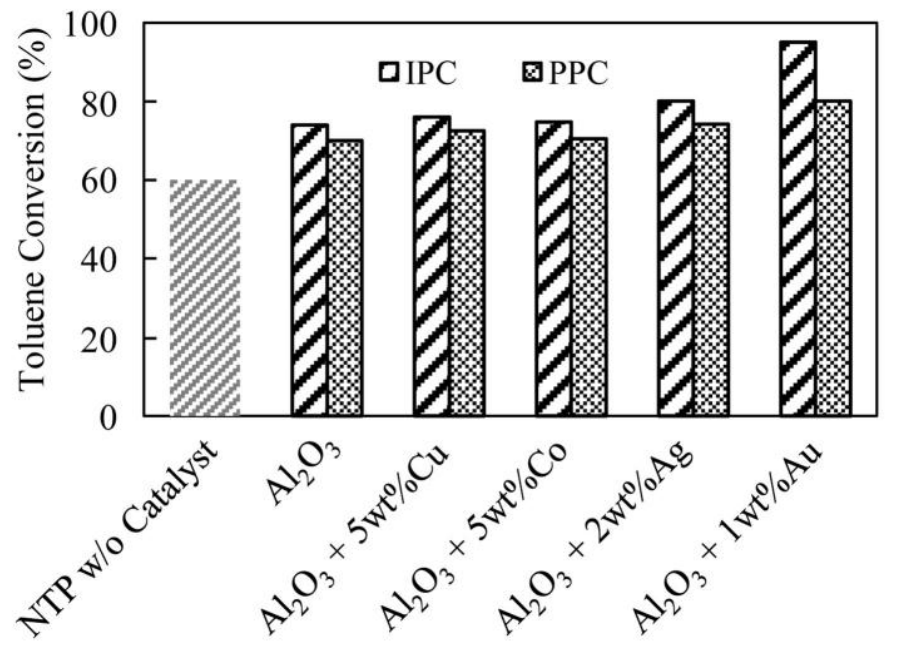

Figure 4: Toluene conversion over $\gamma-\mathrm{Al}_{2} \mathrm{O}_{3}$ metal supported catalysts.

Table 1 summarizes the activity of $\mathrm{CeO}_{2}, \mathrm{Nb}_{2} \mathrm{O}_{5}$ and perovskite catalysts. As shown in previous data, the in-plasma catalysis configuration seems better suited for toluene conversion. When the IPC is operated, the conversion of toluene over various catalysts follows the order:

$\mathrm{CeO}_{2}<\mathrm{LaMnO}_{3} / \mathrm{Al}_{2} \mathrm{O}_{3}<\mathrm{LaMnO}_{3}<\mathrm{La}_{0.7} \mathrm{Ag}_{0.3} \mathrm{MnO}_{3} / \mathrm{Al}_{2} \mathrm{O}_{3}<1 \mathrm{wt} \% \mathrm{Au} / \mathrm{CeO}_{2}<\mathrm{La}_{0.7} \mathrm{Ag}_{0.3} \mathrm{MnO}_{3} ; \mathrm{Nb}_{2} \mathrm{O}_{5}$. 
The products of toluene oxidation measured at the outlet of the plasma-catalyst system are $\mathrm{CO}_{2}, \mathrm{CO}$, and $\mathrm{H}_{2} \mathrm{O}$. In contrast to plasma experiments without catalyst, ozone and NOx are not measured as reaction products. It means that the toluene reaction conversion occurs at room temperature by consumption of $\mathrm{O}_{3}$ and NOx produced by the plasma discharge. Deposit accumulation was observed on the wall of the plasma reactor. This deposit was identified as benzyl alcohol, benzoic acid, and 5-Methyl-2-Nitrophenol.

\begin{tabular}{ccc}
\hline \hline \multirow{2}{*}{ Catalyst } & \multicolumn{2}{c}{ Toluene Conversion (\%) } \\
\cline { 2 - 3 } & PPC & IPC \\
\hline \hline $\mathrm{CeO}_{2}$ & 62 & 75 \\
\hline $1 \mathrm{wt} \% \mathrm{Au} / \mathrm{CeO}_{2}$ & 80 & 90 \\
\hline $\mathrm{LaMnO}_{3}$ & 70 & 85 \\
\hline $\mathrm{LaMnO}_{3} / \mathrm{Al}_{2} \mathrm{O}_{3}$ & 65 & 78 \\
\hline $\mathrm{La}_{0.7} \mathrm{Ag}_{0.3} \mathrm{MnO}_{3}$ & 73 & 92 \\
\hline $\mathrm{La}_{0.7} \mathrm{Ag}_{0.3} \mathrm{MnO}_{3} / \mathrm{Al}_{2} \mathrm{O}_{3}$ & 71 & 88 \\
\hline $\mathrm{Nb}_{2} \mathrm{O}_{5}$ & 89 & 96 \\
\hline \hline
\end{tabular}

Table 1: Toluene conversion over $\mathrm{CeO}_{2}$ and $\mathrm{Al}_{2} \mathrm{O}_{3}$ based catalysts, niobium oxide, and perovskite.

\section{Conclusion}

Atmospheric dielectric barrier discharge was combined to catalysts in two configurations (in-plasma (IPC) and post-plasma (PPC) catalysis) for the abatement of toluene at room temperature. Different catalysts were prepared and characterized and toluene conversions were measured.

Without plasma, the reaction of toluene conversion over different catalysts (perovskite, $\mathrm{Al}_{2} \mathrm{O}_{3}$, and OMS2 based catalysts) is promoted at high temperature (higher than $200^{\circ} \mathrm{C}$, depending on the nature of the catalyst).

In the absence of catalyst, the toluene removal conversions were in the 55-60\% range and the reactions products were $\mathrm{O}_{3}, \mathrm{CO}, \mathrm{CO}_{2}$, and $\mathrm{NOx}$.

When the plasma was combined to catalyst, the toluene removal efficiencies strongly increased when the catalysts were in IPC position. Best toluene removal conversions, up to $96 \%$, were obtained when using $1 \mathrm{wt} \% \mathrm{Au} / \mathrm{Al}_{2} \mathrm{O}_{3}$ and $\mathrm{Nb}_{2} \mathrm{O}_{5}$ catalysts. The products of the $\mathrm{C}_{7} \mathrm{H}_{8}$ oxidation were $\mathrm{CO}$ and $\mathrm{CO}_{2}$.

\section{Acknowledgement:}

The authors would thank the CNRS (French Scientific Research National Center), the VAST (Vietnam Academy of Science and Technology), the GDRI (International Group of Research) "Catalysis for Environment: Depollution, Renewable Energy and Clean Fuels" for their supports, and Dr. J. A. Rodrigues (INPE-Brazil) for providing the $\mathrm{Nb}_{2} \mathrm{O}_{5}$ catalyst.

\section{References}

[1] F. Holzer, U. Roland, F.D. Kopinke, Appl. Catal. B: Environ. 38 (2002) 163-181.

[2] C. Subrahmanyam, M. Magureanu, A. Renken, L. Minsker-Kiwi, Appl. Catal. B: Environ. 65 (2006) $150-156$.

[3] K.P. Francke, H. Miessner, R. Rudolph, Catal. Today 59 (2000) 411-416.

[4] B. Lu, X. Zhang, X. Yu, T. Feng, S. Yao, J. Hazard. Mater. 137 (2006) 633-637.

[5] S. Futamura, H. Einaga, H. Kabashima, L.Y. Hwan, Catal. Today 89 (2004) 89-96.

[6] H. Huang, D. Ye, M. Fu, F. Feng, Plasma Chem. and Plasma Process. 27 (2007) 577-588.

[7] H.H. Kim, A. Ogata, S. Futamura, IEEE Trans. Plasma Sci. 34 (2006) 984-995.

[8] U. Roland, F. Holzer, F.D. Kopinke, Appl. Catal. B: Environ. 58 (2005) 217-226.

[9] N. Blin-Simiand, P. Tardiveau, A. Risacher, F. Jorand, S. Pasquiers, Plasma Process. Plasma Polym. 2 (2005) 256-262. 
[10] M. Magureanu, N.B. Mandache, V.I. Parvulescu, J. Optoelectr. and Adv. Mat. 374 (2005) 16231627.

[11] J. Van Durme, J. Dewulf, C. Leys, H. Van Langenhove, Appl. Catal. B: Environ. 78 (2008) 324-333.

[12] H. Huang, D. Ye, X. Guan, Catal. Today 139 (2008) 43-48.

[13] M.A. Malik, Y. Minamitani, K.H. Schoenbach, IEEE Trans. Plasma Sci. 33 (2005) 50-56.

[14] J. Van Durme, J. Dewulf,W. Sysmans, C. Leys, H. Van Langenhove, Appl. Catal. B: Environ. 74 (2007) 161-169.

[15] H.H. Kim, A. Ogata, S. Futamura, J. Phys. D: Appl. Phys. 38 (2005) 1292-1300.

[16] E. Marotta, A. Callea, M. Rea, C. Paradisi, Environ. Sci. Technol. 41(2007) 5862-5868.

[17] S. Masuda S and H. Nakao, IEEE Trans. Ind. Appl. 26 (1990) 374-383.

[18] S.K. Dhali and I. Sardja, J. Appl. Phys. 69 (1991) 6319-6324.

[19] B.M. Penetrante, M.C. Hsiao, J.N. Bardsley, B.T. Merrit, G.E. Vogtlin, P.H. Wallman, A. Kuthi, C.P. Burkhart and J.R. Bayless, Pure \& Appl. Chem., 68 (5) (1996) 1083-1087.

[20] D. Evans, L.A. Rosocha, G.K. Anderson, J.J Coogan and M.J. Kushner J. Appl. Phys. 74 (1993) 5378-5386.

[21] T. Oda, J. of Electr. 57 (2003) 293-298.

[22] S. Delagrange, L. Pinard, J.M. Tatibouet, Appl. Catal. B. Environ. 68 (2006) 92-98.

[23] Y.F. Guo, D.Q. Ye, K.F. Chen, J.C. He, W.L. Chen, J. Mol. Catal. A: Chem. 245 (2006) 93-100.

[24] R.N. DeGuzman, Y.F. Shen, E.J. Neth, S.L. Suib, C.L. O’Young, S. Levine, J.M. Newsam (1994), Chem. Mater, 6 (1994) 815-821.

[25] R. Zanella, S. Giorgio, C.R. Henry, C. Louis, J. Phys. Chem. B, 106 (2002) 7634-7642. 